\title{
Free will - an approach from the perspective of neuroscience
}

\author{
Liberul arbitru - o abordare din perspectiva neuroștiințelor \\ Adrian Sorin MIHALACHE ${ }^{1,2,3}$, Leon ZĂGREAN ${ }^{3}$ \\ ${ }^{1}$ Facultatea de Teologie Ortodoxă, Universitatea „Alexandru Ioan Cuza“, Iași, România \\ ${ }^{2}$ Centrul de Cercetare în Medicină și Spiritualitate, Spitalul Providența, Iași, România \\ ${ }^{3}$ Universitatea de Medicină și Farmacie „Carol Davila", București, România
}

\section{ABSTRACT}

Free will designates the possibility of conscious and free choice of the subject, as well as his real possibility to act. The topic has a special medical and social relevance as it is directly connected to how the subject's responsibility (moral, legal, medical) for his own actions are understood, but also the possibility (real or illusory) of intervention in his own life.

Free will has received various philosophical, psychological, legal and interdisciplinary approaches in recent decades. In this article we shall inventory some results from the area of neuroscience that we consider relevant in the analysis of free will, research and clinical studies that highlight various effects caused by voluntary actions, consciously repeated by the subject. Some psychotherapeutic interventions, the process of awareness, learning, attention monitoring, visualization, some forms of meditation, and the changes that these practices produce in the processes of neurogenesis, neuroplasticity and epigenetics, in terms of health and quality of life are analysed.

Since these interventions involve the conscious participation of the subject and his voluntary action, we consider that the discussed results are relevant in the debate on free will. The study also highlights the importance of education and social knowledge, as well as the need to promote participatory prevention and therapy, involving the subject in increasing the quality of life and health, through public messages that emphasize the responsibility of each person for their own choices and actions and the impact they have on his life.
\end{abstract}

Keywords: free will, conscious participation, neuroplasticity, neurogenesis, epigenetics, placebo, mindfulness, visualization (mental imaging), the impact of spiritual life on health

\section{REZUMAT}

Liberul arbitru desemnează posibilitatea alegerii conștiente și libere a subiectului, precum și posibilitatea lui reală de a acționa. Tema prezintă o relevanță medicală și socială deosebită, întrucât are implicații directe asupra modului în care sunt înțelese responsabilitatea subiectului (morală, juridică, medicală) pentru propriile sale acțiuni, dar și posibilitatea (reală sau iluzorie) de intervenție în planul propriei vieți.

In ultimele decenii, diverse abordări filosofice, psihologice, juridice și interdisciplinare s-au pronunțat cu privire la liberul arbitru. În articolul de față, inventariem câteva rezultate din aria neuroștiințelor pe care le considerăm relevante în analiza liberului arbitru. Este vorba despre cercetări și studii clinice care evidențiază

Corresponding authors:

Adrian Sorin Mihalache

E-mail: adrian.mihalache@uaic.ro

Article History:

Leon Zăgrean

E-mail: leon.zagrean@gmail.com 
diverse efecte cauzate de acțiunile voluntare, repetate în mod conștient de către subiect. Sunt aduse în discuție unele intervenții psihoterapeutice, procedeul conștientizării, învătarea, monitorizarea atenției, vizualizarea, unele forme de meditație și modificările pe care aceste practici le produc la nivelul proceselor neurogenezei, neuroplasticității și epigenetice, în planul sănătății și al calității vieții.

Intrucât aceste intervenții implică participarea conștientă a subiectului și acțiunea lui voluntară, considerăm că rezultatele discutate prezintă relevanță in dezbaterea privitoare la liberul arbitru. Se evidențiază, totodată, importanța educației și a cunoașterii în plan social, precum și necesitatea promovării unor prevenții și terapeutici participative, care să implice subiectul în creșterea calitativă a vieții și sănătății lui, prin mesaje care să sublinieze responsabilitatea fiecărei persoane pentru alegerile și acțiunile proprii și impactul pe care acestea îl au asupra vieții sale.

Cuvinte cheie: liber arbitru, participare conștientă, neuroplasticitate, neurogeneză, epigenetică, placebo, mindfulness, vizualizare (imagistică mentală), impactul vieții spirituale asupra sănătății

\section{LIBERUL ARBITRU - SCURT INVENTAR TEMATIC DISCIPLINAR ȘI INTERDISCIPLINAR}

Întrucât modul în care înțelegem liberul arbitru corespunde unor capacități reale sau iluzorii de a decide și acționa, tema prezintă o importanță deosebită din perspectivă gnoseologică și practică. Conceptul are un lung parcurs filosofic, începând cu antichitatea greacă $[1,2]$. În ultimele decenii, liberul arbitru a fost analizat în legătură cu diverse concepte, cum ar fi responsabilitatea morală [3] și juridică [4] a subiectului, dar și în raport cu politicile educaționale [5] și cultivarea caracterului [6], cu munca performantă [7] și excelența academică [8], fiind prezent și în evaluarea creațiilor culturale [9]. Sunt cunoscute abordări ale liberului arbitru ca proces decizional $[10,11]$, într-o strânsă legătură cu intenționalitatea [12] și cu actul voluntar [13], dar și în conexiune cu alte concepte precum determinismul, indeterminismul și posibilitatea alegerii [14], sau cu referire la aspecte care privesc conștiența [15] și conștiința [16].

Inevitabilelor discuții de ordin etic despre liberul arbitru [17], li s-au adăugat explorările de ordin genetic [18], clinic [19] și de factură interdisciplinară, cum sunt cele care juxtapun radiografii psihologice, neuro-etice și de teologie morală [20]. În fine, nu lipsesc nici discuțiile speculative, de graniță, care situează liberul arbitru în contextul mecanicii cuantice $[21,22]$ sau al inteligenței artificiale [23], sau cele care analizează condițiile de posibilitate pentru existența liberului arbitru în rândul nevertebratelor [24].

$O$ dovadă a multitudinii perspectivelor sub care este analizat liberul arbitru în câmpul științelor este ilustrată de indexul filosofic PhilPapers. Realizat de o comunitate digitală de specialiști în filosofie, PhilPapers monitorizează surse din aria filozofiei, incluzând texte din periodice, jurnale, cărți și arhive cu acces deschis, dar și din pagini web personale, aparținând unor specialiști, cercetători sau cadre universitare. PhilPapers reprezintă cea mai mare arhivă digitală de texte din aria filosofiei, cu acces liber pentru publicul larg. La data consultării pentru prezentul articol (15 aprilie 2021), PhilPapers conținea 2.570 .856 intrări clasificate, organizate în 5.674 categorii, având peste 280.000 de utilizatori înregistrați [25]. În subcategoria "liberul arbitru și științele" (free will and science), acest inventar digital oferea nu mai puțin de 1016 titluri distincte; dintre acestea, 13 privesc analize ale liberului arbitru în conexiune cu genetica, 351 în legătură cu neuroștiințele, 109 cu fizica, 426 cu psihologia și 103 cu alte științe.

De asemenea, actualitatea și complexitatea temei se pot întrevedea în numeroasele încercări de sistematizare sau de evaluare a liberului arbitru, înregistrate în ultimii ani [26-35].

\section{LIBERUL ARBITRU ȘI RELEVANȚA ÎN PLAN INDIVIDUAL ȘI SOCIAL}

În acest teritoriu vast al abordărilor liberului arbitru, există numeroase perspective. Unele dintre ele refuză realitatea liberului arbitru [36], altele o susțin răspicat [37]. Dincolo de numeroasele aspecte provocatoare și complexe pe care le comportă, tema este importantă în planul vieții personale și sociale [38]. Sunt multe motive care susțin acest fapt: necesitatea de a clarifica răspunderea morală și juridică pentru acțiunile noastre, posibilitatea reală de a alege între diverse opțiuni, pentru a fi considerați, cu temei, autorii propriilor noastre alegeri și fapte, participarea conștientă la deciziile și acțiunile care ne sunt atribuite în plan social sau în privința stilului de viață [39].

La nivel individual, modul în care este înțeles liberul arbitru furnizează o reprezentare despre capacitatea reală sau iluzorie de a schimba tiparele propriei vieți, de a înlocui obișnuințele nesănătoase cu practici sano- 
gene. Argumentând un model sau altul de înțelegere a liberului arbitru, informația științifică poate spori responsabilitatea subiectului pentru propriile alegeri și acțiuni, sau, dimpotrivă, îl poate degreva de această răspundere.

Un studiu remarcă această influență a discursului științific referitor la liberul arbitru în autoraportarea subiecților la adicție [40]. Sunt discutate informațiile științifice care susțin o diminuare a liberului arbitru în cazul subiecților dependenți de alcool; accentuând dezechilibrul neurologic și aspectele deterministe al adicției, ele susțin indirect o scădere a posibilităților de care dispun subiecții adictivi pentru alegerile pe care le fac și pentru acțiunile lor. Pe de altă parte, abordările etice sau morale ale alcoolismului prezintă comportamentele alcoolicilor drept rezultatul alegerilor lor, evoluția situației depinzând în continuare de deciziile subiecților în cauză. După ce remarcă aceste deosebiri la nivelul discursului public, studiul subliniază că informația științifică despre posibilitatea reală sau iluzorie de alegere a comportamentelor poate modifica autopercepția subiecților adictivi. Un discurs care minimalizează posibilitățile unor alegeri conștiente și libere și ale acțiunilor voluntare poate intensifica autodeprecierea și stigmatizarea persoanelor adictive, alimentate de conștientizarea propriilor carențe în luarea deciziilor, de acceptarea deficitului de autocontrol [40].

În opinia noastră, pe lângă cercetările care vizează aspecte conceptuale sau modele teoretice, juridice, psihologice sau interdisciplinare, liberul arbitru poate fi apreciat și printr-o serie de rezultate și descoperiri din aria neuroștiințelor clinice. Ne referim aici la cele care privesc neuroplasticitatea, neurogeneza sau epigenetica, dar și la cele care au în atenție fenomenul placebo, modificările antrenate de psihoterapia cognitiv-comportamentală și de experiența vieții spirituale.

\section{NEUROPLASTICITATE AUTOINDUSĂ}

Neuroplasticitatea vizează un spectru larg de procese, fiind evidențiată la unele specii de mamifere [41] și la oameni [42]. Ea însoțește etapele obișnuite de dezvoltare ale unui creier sănătos, dar cuprinde și modificările structurale și funcționale adaptative sau maladaptative ale țesutului cerebral, care apar pe durata întregii vieți, ca urmare a experiențelor (input senzorial), fiind responsabilă și de modificările de receptare și prelucrare a datelor experienței [43].

Neuroplasticitatea este prezentă astăzi într-un spectru larg de intervenții terapeutice, de la cele evidențiate de Edward Taub, în recuperarea postAVC [44], până la cele care urmăresc identificarea unor ținte moleculare pentru a ameliora plasticitatea în bolile neurodegenerative [45]. În privința plasticității sinaptice, de exemplu, PubMed indică un total de peste 66.000 de intrări, începând cu 2009, anual înregistrându-se peste 3000 de articole [46]. Cercetări și studii clinice care au explorat neuroplasticitatea prezintă rezultate încurajatoare în boala Alzheimer, în cazul leziunile medulare, în apraxie sau în reabilitarea motorie postAVC [47]. În alt registru, adoptarea unor comportamente sanogene, cum ar fi exercițiile fizice periodice și alimentația sănătoasă, ameliorează procesele de adaptare neuronală [48].

În diverse forme, în situații de acest fel, în miezul intervenției se află acțiunea conștientă a subiectului, efectele neuronale observabile fiind, cel mai adesea, rezultatul unui exercițiu repetat în mod voluntar. De exemplu, adoptarea unor comportamente sănătoase contribuie la sporirea producției factorului neurotrofic derivat din creier (BDNF). Este binecunoscut că nivelul de BDNF influențează funcția cognitivă și că în unele afecțiuni, cum ar fi depresia severă $[49,50]$, Alzheimer [51] sau diabetul de tip II [52], valorile BDNF sunt scăzute. Impactul adoptării unor practici zilnice este evident în privința sportului, întrucât exercițiile fizice moderate, chiar și pentru o durată de doar 30 de minute, au efecte asupra nivelului de BDNF [53], contribuind la sporirea atenției selective [54] și a capacităților de învățare [55], determinând și modificări cerebrale structurale [56].

\section{INTERVENTIII PENTRU STIMULAREA NEUROGENEZEI}

Relevante, în chestiunea liberului arbitru, sunt și descoperirile care evidențiază influența acțiunilor și comportamentelor voluntare asupra neurogenezei. Localizate în hipocamp și în girusul dentat [57], procesele de formare a neuronilor noi prin diferențierea celulelor stem neuronale au fost evidențiate și la adulți [58]. Neurogeneza prezintă o deosebită importanță, având potențial regenerativ [59]. Și în cazul acestor procese, există situații în care voința, implicarea și acțiunea conștientă a subiecților se dovedesc decisive.

Unele studii arată că alegerea unui ambient social adecvat [60] sau diversificarea experiențelor și îmbogățirea mediului de viață pot stimula neurogeneza [61]. Alte exemple sunt furnizate de studiile care vizează intervențiile de factură cognitiv-comportamentală pentru ameliorarea răspunsului la stres. Sunt cunoscute efectele stresului la nivelul proceselor celulare, în arhitectura dendritică și în privința nivelurilor factorilor de creștere [62]. Impactul stresului este extins, afectând transmiterea semnalelor în sistemul nervos și conexiunile acestuia, procesele neurogenezei [63] și neuroplasticității [64], dar și tabloul clinic general [65]. Intervențiile cognitiv-comportamentale pentru ameliorarea răspunsului la stres [66] sunt relevante în discuția despre liberul arbitru, pentru că produc o schimbare printr-un set de acțiuni la care pacienții participă 
conștient. De exemplu, postul intermitent [67], exercițiile fizice $[68,69]$ și dieta $[70]$ pot stimula procesele neurogenezei. De asemenea, există unele studii care anunță impactul benefic al strategiilor de coping în reglarea proceselor neurogenezei, fapt evidențiat mai întâi la maimuțe [71], dar luat în discuție și la oameni [72].

\section{EPIGENETICĂ AUTODIRECȚIONATĂ}

Și aria epigeneticii furnizează rezultate care merită luate în discuție în dezbaterea despre liberul arbitru, din același motiv. Este vorba despre procesele de metilare/demetilare a ADN-ului, despre acetilarea/deacetilarea proteinelor (în principal histone), de activitatea microARN-urilor (miARN) care însoțesc modificarea expresiilor genelor și a funcțiilor pe care aceste gene le codifică. Și în aceste cazuri, există dovezi care privesc plasticități autoinduse, prin efortul conștient, prin acțiunile voluntare.

Un exemplu îl constituie studiile care evaluează ameliorarea efectelor epigenetice ale stresului prin intervenții cognitiv-comportamentale. Este cunoscut că expunerea la stres, în perioada timpurie a vieții poate produce modificări în expresia genelor, la nivelul proceselor de metilare $[73,74]$. Unele studii evidențiază cum comportamentul matern și ambientul social influențează răspunsul la stres la exemplarele de șoareci [75] și maniera în care atașamentul poate ameliora epigenetica răspunsului la stres în cazul oamenilor, la adulții tineri [76]. Recadrarea cognitivă (cognitive reappraisal), psihoterapia cognitiv-comportamentală [77] sau alte intervenții psihoterapeutice [78], dar și simple modificări de ordin comportamental, cum ar fi alegerea unui mediu de viață sanogen și o dietă sănătoasă [79] sau exerciții fizice regulate [80], pot influența semnificativ expresia genelor. Este vorba despre reglarea unor expresii genetice (down-shifting sau up-shifting) care modifică mecanisme fiziologice corelative, ameliorând calitatea vieții [81]. În particular, modificări ale tiparelor de viață pot influența scăderea expresiei proinflamatorii și chiar răspunsul transcripțional conservat la adversitate (RTCA) - care cuprinde expresia genelor implicate în răspunsul inflamator și infecțios [82], fapt care contribuie la ameliorarea sănătății [83].

În discuția despre liberul arbitru, sunt semnificative și studiile care semnalează influența stresului cronic [84] asupra plasticității telomerilor [85] și, prin aceasta, impactul asupra duratei de viață. Și în acest caz, intervențiile terapeutice de ameliorare a răspunsului la stres se dovedesc eficiente. Nu este vorba doar de perioadele timpurii de viață, când plasticitatea telomerilor pare să fie sub influența atașamentului matern [86], ci și despre acțiuni conștiente, repetate voluntar de către pacienți adulți, acțiuni care pot să producă modifi- cări semnificative. Metoda rezilienței multisistem (multisystem resiliency) [87], de exemplu, vizează reglarea emoțională, consolidarea conexiunilor sociale și adoptarea comportamentelor sănătoase, acestea influențând benefic plasticitatea telomerilor. Un studiu a arătat că intervenția aplicată unui grup de persoane adulte, cu vârste cuprinse între 45 și 90 de ani, a determinat o ușoară creștere a lungimii telomerilor și o scădere în intensitate a episoadelor de depresie [88]. Alte studii arată o plasticitate a telomerilor, în stadiul de adult, prin cultivarea unor rutine sănătoase [89-92].

Odată cu epigenetica, intră în discuție și procese noi, de natură epigenetic-transgenerațională, care pot interfera cu procesul decizional [93], alimentând în plan științific și la nivelul publicului larg perspective deterministe [94]. Cu toate acestea, credem că studiile menționate arată într-un mod convingător că putem spori implicarea conștientă și activă în păstrarea propriei sănătăți și că există modalități de prevenție și posibilități de intervenție terapeutică, direcționate către răspunsuri epigenetice [95].

\section{REMISII SPONTANE, PLACEBO ȘI FACTORI DE ORDIN PERSONAL}

Argumente în favoarea liberului arbitru, care susțin că propriile alegeri și acțiuni ne influențează viața și sănătatea, sunt furnizate de studiul fenomenului placebo și de cele care urmăresc remisiile spontane.

Fenomenul placebo [96] a înregistrat o prezență crescută în abordările științifice ale ultimilor decenii [97]. Studiile remarcă o eficacitate, în diverse grade, a acestui efect, în ameliorarea răspunsului la stres și recuperare postoperatorie [98], în migrene [99] și anxietate [100], în artrita reumatoidă [101] și în sindromul tunelului carpian [102], în fibromialgie [103], în cazul alergiilor [104], în durerea cronică [105] și în ulcerul duodenal [106], dar și în depresie [107] și cancer [108]. De exemplu, o metaanaliză indică o rată de eficacitate de $29 \%$ prin placebo, comparativ cu $36 \%$ prin intervenții medicale clasice [109].

În ultimii ani, au apărut abordări care propun investigații genetice asupra subiecților care răspund la placebo. Este vorba despre aria numită placebom, care inventariază particularitățile genomice ale pacienților care răspund la placebo și posibilitățile terapeutice care decurg de aici [110]. Unul dintre autorii recunoscuți în acest domeniu a avertizat, la finalul unui studiu mai vechi, asupra faptului că existența efectului placebo sugerează extinderea "concepției privind capacitățile umane" [111].

Aici, încadrăm și interesul științific tot mai mare pentru remisiile spontane. Este vorba despre unele studii de caz [112-115] și metaanalize [116-119], care afirmă necesitatea clarificărilor științifice privind rolul unor 
aspecte de ordin subiectiv precum rugăciunea [120] sau alți factori psihologici [121] în procesul de remisie spontană.

Studiile despre eficacitatea efectului placebo sau despre condițiile de posibilitate pentru remisia spontană merită luate în discuție în evaluarea liberului arbitru, întrucât avem de-a face cu un proces în care sunt decisive complianța, credința în efectul binefăcător al tratamentului [122], convingerile organizate superior, datele cunoașterii [123], credința și practica religioasă [124].

\section{AUTOCONTROLUL ATENȚIEI, ÎNVĂȚTARE ȘI CONȘTIENTIZARE}

Relevante în inventarul posibilităților terapeutice capabile să producă plasticitate autoindusă sunt și acele studii (evidence-based medicine) privitoare la modificările cerebrale determinate prin direcționarea conștientă a gândurilor. Antrenamentul mental adecvat, de exemplu, cultivat prin efort voit, poate afecta circuitele cerebrale patologice, determinând o alterare adaptativă. Este cazul unor reușite obținute prin intervenții terapeutice în tratamentul OCD (obssesive compulsive disorder) [125], în fobii, anxietăți sau în sindromul posttraumatic [126].

Intervențiile terapeutice care urmăresc controlul activității mentale conștiente constau în tehnici de auto- sau refocusare a atenției, procedee de creștere a gradului de conștientizare [127] sau de însușire a unor strategii de coping [128], efortul de învățare fiind vectorul principal în creșterea rezilienței și neuroadaptarea funcțională. Practic, semnificația asociată unei acțiuni reconfigurează efectele acelei acțiuni asupra subiectului care acționează, în măsura în care acesta conștientizează semnificația respectivă. De exemplu, un studiu a arătat că informarea unor menajere cu privire la efectele benefice ale activităților lor asupra sănătății a sporit impactul benefic al muncii prestate comparativ cu un alt grup de menajere care au desfășurat activități similare, dar care nu au fost informate cu privire la impactul sanogen al muncii lor [129]. Și în acest caz, intervine în discuție participarea conștientă a subiectului la activitățile pe care le desfășoară, o modalitate mentală de raportare la propriile sale acțiuni (mindset).

Alte studii, în care subiecților li se cere sporirea gradului de conștientizare a unei acțiuni sau învățarea unei mișcări noi, prezintă, de asemenea, relevanță pentru discuția despre liberul arbitru. De exemplu, s-a constatat că harta neuronală corelativă unei sarcini de conștientizare vizuală este mai extinsă, cuprinzând și centrii cerebrali superiori, spre deosebire de amprenta cerebrală corespunzătoare unei sarcini de atenție vizuală $[130,131]$. Într-un alt studiu găsim că amprenta ce- rebrală corespunzătoare eforturilor de învățare pentru deprinderea unei mișcări noi (însoțită de un efort conștient) se deosebește de cea activă în desfășurarea automată a aceleași mișcări [132]. Aceste rezultate aduc în discuție învățarea ca efort conștient de a reține unele informații sau de însușire a unor mișcări și diferența calitativă pe care o produce efortul de conștientizare la nivelul rețelelor cerebrale [133]. În acest sens, au fost identificate și unele particularități, în cazul matematicienilor [134] sau al celor care cultivă meditația [135].

Pe de altă parte, dirijând conștient atenția către anumiți stimuli, subiectul influențează propriile percepții și procesarea neuronală a semnalelor. Focusarea intenționată a atenției pe anumiți stimuli din câmpul senzorial determină o prelucrare diferențiată a semnalelor selectate (eveniment), în raport cu toate celelalte semnale (zgomot de fond). Atenția voluntară modulează comunicarea neuronală (top-down), determinând o creștere a eficacității prelucrării inputului presinaptic și a răspunsului postsinaptic, în cazul semnalului urmărit, și o scăderea a eficacității în prelucrarea semnalelor redundante, fapt care permite receptarea îmbunătățită a stimulilor selectați (eveniment) în raport cu zgomotul de fond [136].

Mai departe, urmărirea cu atenție a unor imagini poate produce efecte fiziologice măsurabile, o posibilă explicație fiind neuronii oglindă [137]. Unele studii au raportat creșterea lungimii degetelor printr-un training de vizualizare a unor materiale sugestive [138], dar și ameliorarea stării unor pacienți care au suferit un AVC [139] când aceștia au urmărit materiale video cu un conținut special adaptat.

\section{PLASTICITATE AUTOINDUSĂ PRIN IMAGISTICĂ MENTALĂ}

Un loc important în discuția privitoare la plasticitatea autoindusă îl au studiile care evidențiază impactul gândirii și al imaginilor mentale asupra funcționării cerebrale. Unul dintre primele studii care au deschis acest câmp de lucru a dovedit că simpla exersare mentală a unei acțiuni produce modificări neuronale similare celor provocate de efectuarea propriu-zisă a acțiunii $[140,141]$. Ulterior acestui rezultat, alte studii au arătat importanța gândurilor și a imaginilor mentale asupra fiziologiei. Reprezentarea mentală a unei mișcări a degetelor de la mâini și de la picioare, dar și a limbii produce activitate în regiunile cerebrale care le guvernează [142], iar antrenamentul imaginar direcționat produce o creștere a puterii fizice $[143,144]$.

Vizualizarea mentală (sau imagistică mentală) a fost testată cu rezultate încurajatoare în diverse afecțiuni, cu rezultate notabile în vindecarea rănilor postoperatorii [145] și diminuarea durerilor în fibromialgie [146], în 
recuperarea postAVC [147] și în ameliorarea durerilor cauzate de cistită [148], în reabilitarea după o leziune a măduvei spinării [149]. Există rezultate notabile ale terapiei prin imagistică mentală, fiind evidențiate ameliorări ale stării pacienților cu astm [150] și Parkinson [151], scăderi ale nivelului de stres și ale condițiilor de recurență în cancerul de sân [152], ameliorarea calității vieții pacientelor cu osteoartrită [153], dar și consolidarea stării de calm la pacienții cu boli pulmonare [154].

În aceste cazuri, avem de-a face cu pacienți care cultivă imagini mentale specifice, obținând ameliorări sensibile, fapt care indică impactul important al gândurilor și reprezentărilor mentale asupra sănătății și vieții.

\section{MINDFULNESS, EXPERIENTTE RELIGIOASE ȘI SPIRITUALE}

Posibilitatea unor intervenții reale, capabile să producă schimbări semnificative în planul sănătății și al vieții, este susținută și de studiile care evaluează practicile mentale și experiențele cu caracter spiritual.

În ultimul deceniu, au fost investigate neuroștiințific diverse forme de autocontrol mental, practici meditative cum ar fi răspunsul de relaxare (relaxation response) și mindfulness [155], mindfulness based stress reduction - MBSR [156], mind-body therapy [157] și posibilele lor efecte în planul sănătății. Rezultatele sunt semnificative în tratamentul sindromului posttraumatic [158], anxietății [159] și depresiei [160], în reglarea nivelului de cortizol [161], în reglarea nivelului glucozei saguine, la pacienții cu diabet de tip 2 [162], în potențarea neurogenezei [163], dar și posttransplant, reducând depresia și anxietatea și îmbunătățind calitatea somnului pacienților [164].

Un studiu a arătat eficiența unui program de reducere a stresului bazat pe cultivarea atenției (metoda MBSR), desfășurat pe durata a 8 săptămâni, în cazul a 49 de paciente cu cancer de sân și a 10 pacienți cu cancer de prostată, toți în stadiu incipient. Programul a inclus reprize de relaxare, tehnici de meditație practicate zilnic la domiciliu. Măsurătorile, făcute înainte și după intervenția chirurgicală, au evidențiat modificări în parametrii endocrini, imuni și autonomi, în privința nivelurilor de cortizol salivar, în privința numărului celulelor imune, a tensiunii arteriale și a ritmului cardiac [165].

Alte rezultate subliniază că programul MBSR poate contribui la îmbunătățirea calității vieții [166], determinând o reducere a nivelului de stres la pacienții cu diverse forme de cancer [167]. În unele cazuri, eficacitatea intervenției este rapidă, dacă ținem seama de concluziile unui alt studiu, care a evidențiat, după numai 8 ore de practică a meditației, modificări în mecanismele inflamatorii (scăderea nivelului interleukinei-8, citokină proinflamatorie) [168].
Numeroase alte rezultate fac referire la alte practici cu caracter spiritual. Avem în vedere aici efectul Maica Tereza, evidențiat de David McClelland [169], care semnalează modificarea răspunsului imunitar ca urmare a unei experiențe cu un conținut spiritual, dar și efectele terapeutice ale compasiunii [170-172]. La acest capitol, sunt relevante și studiile care identifică amprentele cerebrale și efecte psiho-emoționale distincte de pe urma diverselor practici spirituale sau religioase, evidențiate de Andrew Newberg în cercetările din cadrul neuroteologiei $[173,174]$.

Sunt remarcabile și concluziile metaanalizelor realizate de Harold Koenig, pe marginea studiilor privitoare la efectele terapeutice ale vieții religioase sau spirituale. Într-una dintre aceste metaanalize ample, evaluând 1200 de studii medicale apărute între anii 1872 și 2000, și 2100 de studii apărute între anii 2000 și 2010, sunt evidențiate corelațiile strânse între religie/spiritualitate și diverse aspecte ale sănătății [175]. Operând o selecție riguroasă, care a ținut seama de criterii de probitate științifică, schema experimentală și corectitudinea analizei datelor, metaanaliza a oferit o radiografie științifică a raportului dintre viața religioasă și sănătate, la nivelul anului 2010. Concluziile indică un impact benefic semnificativ al practicilor vieții spirituale și religioase în bolile coronariene, hipertensiunea arterială, bolile cerebro-vasculare, boala Alzheimer și demență, în reglarea funcției imunitare și a funcției endocrine, în evoluția cancerului, în calitatea motricității (mobilitate și capacități fizice) și a sănătății și în privința speranței de viață [175]. În plus, viața spirituală are un impact benefic în configurarea răspunsului la stres, în cultivarea emoțiilor pozitive, în starea de bine, în cultivarea speranței și a optimismului, în consolidarea sentimentului unei vieți cu rost, în creșterea stimei de sine, în trăsăturile de caracter pozitive, reducând, totodată, incidența depresiei și a sinuciderilor, a anxietății și abuzului de substanțe, a delincvenței și instabilității maritale [175].

O altă metaanaliză, condusă de același medic [176], a evaluat legătura dintre viața spirituală/religioasă (R/S) și sănătatea mintală, surprinsă de studiile științifice publicate în jurnale de specialitate pe durata a 20 de ani, între anii 1990 și 2010. Au fost examinate cercetările originale despre religie, religiozitate, spiritualitate și termenii aferenți, publicate în primele $25 \%$ dintre jurnalele de psihiatrie și neurologie, în conformitate cu clasamentele indexului ISI 2010. În procente, $72,1 \%$ dintre cercetările analizate au evidențiat o relație pozitivă între nivelul implicării religioase/spirituale și prezența mai redusă a tulburărilor mintale. Toate studiile privind demența, sinuciderea și tulburările cauzate de stres au constatat o asociere pozitivă a R/S, 79\% dintre ele au constatat că R/S corelează cu un nivel scăzut de depresie și 67\% dintre ele cu abuzul scăzut de substanțe [177]. 
Alte abordări merg chiar mai departe, forțând teritorii noi, vizând posibile efecte ale activității mentale asupra neurogenezei și asupra expresiei ADN-ului [178] sau impactul epigenetic al răspunsului de relaxare (the relaxation response) [179]. Un exemplu semnificativ aici îl reprezintă un studiu care a urmărit modificările provocate de o practică meditativă care a vizat sensul vieții. Practicanții au înregistrat - după 6 ore de meditație zilnică, timp de 3 luni de zile petrecute în retragere - modificări importante la nivelul celulelor imune, o scădere a afectivității negative, creșterea activității telomerazei, creșterea lungimii telomerilor și o longevitate sporită a celulelor imune [180].

Chiar dacă analiza minuțioasă a rezultatelor de acest fel este abia la început [181-183], considerăm că studiile de acest fel rămân semnificative pentru discuțiile referitoare la posibilitățile reale de alegere și de schimbare a vieții, luate în discuție cu referire la liberul arbitru.

\section{CONCLUZII}

Dezbaterile privitoare la liberul arbitru pun în discuție diverse concepte și nuanțe filosofice și psihologice. Pe lângă aceste considerații, studiile clinice și cercetările experimentale din aria neuroștiințelor furnizează un volum important de rezultate care merită atenția în evaluarea liberului arbitru. Miza este importantă, întrucât avem de-a face cu posibilitatea intervenției voite, conștiente, în planul vieții personale. Cercetările inventariate pe scurt aici indică diverse posibilități de implicare a subiectului, care pot ameliora suferința, pot contribui la recuperarea sau dezvoltarea unor abilități, pot stimula emoționalitatea pozitivă, pot schimba patternuri de gândire și acțiune, contribuind considerabil la îmbunătățirea calității vieții.

Conflict of interest: none declared Financial support: none declared

\section{BIBLIOGRAFIE}

1. Frede M. A Free Will: Origins of the Notion in Ancient Thought, Long AA (ed) series: Sather Classical Lectures. University of California Press; 2011.

2. Cary P. A brief history of the concept of free will: issues that are and are not germane to legal reasoning. Behav Sci Law. 2007;25(2):165-81.

3. Levy N, McKenna M. Recent Work on Free Will and Moral Responsibility. Philos Compass. 2009 Jan 21;4(1):96-133.

4. Kolber AJ. Free Will as a Matter of Law in Philosophical Foundations of Law and Neuroscience, Patterson D, Pardo MS (eds.). Oxford Scholarship Online; 2016.

5. Giesinger J. Free Will and Education. J Philos Educ. 2010 Nov;44(4):515-28.

6. Danto AC, Morgenbesser S. Character and Free will. J Philos. 1957 Aug; 54(16):493-505.

7. Stillman TF, Baumeister RF, Vohs KD, Lambert NM, Fincham FD, Brewer LE. Personal Philosophy and Personnel Achievement: Belief in Free Will Predicts Better Job Performance. Soc Psychol Personal Sci. 2010;1(1):43-50.

8. Feldman G, Chandrashekar P, Wong KFE. The Freedom to Excel: Belief in Free Will Predicts Better Academic Performance. Pers Individ Dif. 2016 Feb 90:377-83.

9. Bartra R. Anthropology of the Brain: Consciousness, Culture, and Free Will, Cambridge University Press; 2014.

10. Yoder KJ, Decety J. The neuroscience of morality and social decision-making. Psychol Crime Law. 2018;24(3):279-295.

11. Burns K, Bechara A. Decision making and free will: a neuroscience perspective. Behav Sci Law. 2007;25(2):263-80.
12. Leisman G, Macahdo C, Melillo R, Mualem R. Intentionality and "free-will" from a neurodevelopmental perspective. Frontiers in Integrative Neuroscience. 2012;6:36.

13. Libet B. Unconscious cerebral initiative and the role of conscious will in voluntary action. Behav Brain Sci.1985;8(4):529-539.

14. Atmanspacher H, Bishop R. Between Chance and Choice. Interdisciplinary Perspectives on Determinism. Imprint Academic Thorverton; 2002.

15. Shepherd J. Free will and consciousness: experimental studies. Conscious Cogn. 2012 Jun;21(2):915-27.

16. Lavazza A. Free Will and Neuroscience: From Explaining Freedom Away to New Ways of Operationalizing and Measuring It. Front Hum Neurosci. 2016 Jun 1;10:262.

17. Zürcher $T$, Elger $B$, Trachsel $M$. The notion of free will and its ethical relevance for decision-making capacity. BMC Med Ethics. 2019 May 8;20(1):31.

18. Alper JS. Genes, free will, and criminal responsibility. Soc Sci Med. 1998 Jun;46(12):1599-611.

19. Meynen G. Free will and mental disorder: exploring the relationship. Theor Med Bioeth. 2010 Dec;31(6):429-43.

20. Dodson GF. Free Will. Neuroethics, Psychology and Theology. Vernon Series in Philosophy. Hardcover; 2017.

21. Stapp HP. Philosophy of Mind and the Problem of Free Will in the Light of Quantum Mechanics. internet], citat 2021 Sep 8]. Available at: https://arxiv.org/ftp/ arxiv/papers/0805/0805.0116.pdf.

22. Stapp HP. Quantum Theory and Free Will: How Mental Intentions Translate into Bodily Actions. Springer International; 2017.
23. Krausová A, Hazan H. Creating Free Will in Artificial Intelligence. Beyond Al: Artificial Golem Intelligence. Proc Int Conf Beyond Al. Pilsen. Czech Republic. University of Bohemia; 2013 November12-14: 96-109.

24. Brembs B. Towards a scientific concept of free will as a biological trait: spontaneous actions and decision-making in invertebrates. Proc Biol Sci. 2011 Mar 22;278(1707):930-9.

25. PhilPapers. Available at: https://philpapers. org/browse/free-will-and-science.

26. Dennett DC, E Room. The Varieties of the Free Will Worth Wanting. MIT Press; 1984.

27. Kane R. The Significance of Free Will. Oxford University Press; 1996.

28. Responsibility and the Moral Sentiments. Harvard University Press; 1998.

29. Dilman I. Free Will: An Historical and Philosophical Introduction. Routledge; 1999.

30. Kane R. A Contemporary Introduction to Free Will. Oxford University Press; 2005.

31. Fischer JM, Kane R, Pereboom D, Vargas M. Four Views on Free Will. (Great Debates in Philosophy). Blackwell; 2014.

32. Waller BN. Against Moral Responsibility. MIT Press; 2011.

33. Kane R. The Oxford Handbook of Free Will (second edition). Oxford University Press; 2011.

34. Iredale M. The Problem of Free Will: A Contemporary Introduction. Routledge; 2012.

35. McKenna M, Pereboom D, Free Will: A Contemporary Introduction. Routledge; 2014.

36. Wegner DM. The Illusion of Conscious Will. The MIT Press; 2002. 
37. List C. Why Free Will Is Real. Harvard University Press; 2019.

38. Kane R. A Contemporary Introduction to Free Will. New York. NY: Oxford University Press; 2005.

39. Lavazza A. Free Will and Neuroscience: From Explaining Freedom Away to New Ways of Operationalizing and Measuring It. Front Hum Neurosci. 2016 Jun 1;10:262.

40. Racine, E, Bell, E, Zizzo, N, Green, C. Public discourse on the biology of alcohol addiction: implications for stigma, self-control, essentialism, and coercive policies in pregnancy. Neuroethics. 2015;8:177-86.

41. La Rosa C, Bonfanti L. Brain Plasticity in Mammals: An Example for the Role of Comparative Medicine in the Neurosciences. Frontiers in veterinary science. 2018 Nov 1;5:274

42. Zoladz JA, Pilc A. The effect of physical activity on the brain derived neurotrophic factor: from animal to human studies. $J$ Physiol Pharmacol. 2010 Oct;61(5):533-41.

43. Rivera SM, Carlson SM, Zelazo P. Introduction to Special Issue: Current Perspectives on Neuroplasticity, Cogn Dev. 2017; 42:1-3.

44. Taub E, Miller NE, Novack TA, Cook EW 3rd, Fleming WC, Nepomuceno CS, Connell JS, Crago JE. Technique to improve chronic motor deficit after stroke. Arch Phys Med Rehabil. 1993 Apr; 74(4):347-54

45. Kozubski W, Ong K, Waleszczyk W, Zabel M, Dorszewska J. Molecular Factors Mediating Neural Cell Plasticity Changes in Dementia Brain Diseases. Neural Plast. 2021 Mar 29;2021:8834645.

46. National Library of Medicine. Sinaptic plasticity. Available at: https://pubmed.ncbi. nlm.nih.gov/?term=sinaptic $\% 20$ plasticity\&sort=date\&timeline=expanded.

47. Baudry M, Bi X,. Schreiber SS. Synaptic Plasticity. Basic Mechanisms to Clinical Applications. CRC Press, 2005:229-80.

48. Peterson JC. The adaptive neuroplasticity hypothesis of behavioral maintenance. Neural Plast. 2012;2012:516364.

49. Lang UE, Hellweg R, Gallinat J. BDNF serum concentrations in healthy volunteers are associated with depression-related personality traits.

Neuropsychopharmacology. 2004 Apr;29(4):795-8.

50. Emon MPZ, Das R, Nishuty NL, Shalahuddin Qusar MMA, Bhuiyan MA Islam MR. Reduced serum BDNF levels are associated with the increased risk for developing MDD: a case-control study with or without antidepressant therapy. BMC Res Notes. 2020 Feb 21;13(1):83.

51. Connor B, Young D, Yan Q, Faull RL, Synek $B$, Dragunow M. Brain-derived neurotrophic factor is reduced in Alzheimer's disease. Brain Res Mol Brain Res. 1997 Oct 3;49(1-2):71-81.

52. Krabbe KS, Nielsen AR, Krogh-Madsen R, Plomgaard P, Rasmussen P, Erikstrup C, Fischer CP, Lindegaard B, Petersen AM,
Taudorf S, Secher NH, Pilegaard H, Bruunsgaard H, Pedersen BK. Brainderived neurotrophic factor (BDNF) and type 2 diabetes. Diabetologia. 2007 Feb;50(2):431-8.

53. Gold SM, Schulz KH, Hartmann S, Mladek M, Lang UE, Hellweg R, Reer R, Braumann $\mathrm{KM}$, Heesen $\mathrm{C}$. Basal serum levels and reactivity of nerve growth factor and brain-derived neurotrophic factor to standardized acute exercise in multiple sclerosis and controls. J Neuroimmunol. 2003 May;138(1-2):99-105.

54. Isbell E, Stevens C, Pakulak E, Hampton Wray A, Bell TA, Neville HJ. Neuroplasticity of selective attention: Research foundations and preliminary evidence for a gene by intervention interaction. Proc Natl Acad Sci U S A. 2017 Aug 29;114(35):9247-9254.

55. Green CS, Bavelier D. Exercising your brain: a review of human brain plasticity and training-induced learning. Psychol Aging. 2008 Dec;23(4):692-701.

56. Rogge AK, Röder B, Zech A, Hötting K. Exercise-induced neuroplasticity: Balance training increases cortical thickness in visual and vestibular cortical regions. Neuroimage. 2018 Oct 1;179:471-479.

57. Eriksson PS, Perfilieva E, Björk-Eriksson T, Alborn AM, Nordborg C, Peterson DA, Gage FH. Neurogenesis in the adult human hippocampus. Nat Med. 1998 Nov;4(11):1313-7.

58. Kempermann $\mathrm{G}$, Song $\mathrm{H}$, Gage FH. Neurogenesis in the Adult Hippocampus. Cold Spring Harb Perspect Biol. 2015 Sep 1;7(9):a018812.

59. Kumar A, Pareek V, Faiq MA, Ghosh SK, Kumari C. Adult neurogenesis in humans: A Review of Basic Concepts, History, Current Research, and Clinical Implications. Innov Clin Neurosci. 2019 May 1;16(5-6):30-37.

60. Lu L, Bao G, Chen H, Xia P, Fan X, Zhang J, Pei G, Ma L. Modification of hippocampal neurogenesis and neuroplasticity by social environments. Exp Neurol. 2003 Oct;183(2):600-9

61. Kempermann G, Gast D, Gage FH. Neuroplasticity in old age: sustained fivefold induction of hippocampal neurogenesis by long-term environmental enrichment. Ann Neurol. 2002 Aug;52(2):135-43.

62. McEwen BS. Stress and hippocampal plasticity. Annu Rev Neurosci. 1999; 22:105-22.

63. Mirescu C, Gould E. Stress and adult neurogenesis. Hippocampus; 2006;16(3):233-8.

64. Pittenger C, Duman RS. Stress, depression, and neuroplasticity: a convergence of mechanisms. Neuropsychopharmacology. 2008 Jan;33(1):88-109.

65. Yaribeygi $H$, Panahi $Y$, Sahraei $H$, Johnston TP, Sahebkar A. The impact of stress on body function: A review. EXCLI J. 2017 Jul 21:16:1057-1072

66. Davidson RJ, McEwen BS. Social influences on neuroplasticity: stress and interventions to promote well-being. Nat Neurosci. 2012 Apr 15;15(5):689-95.

67. Baik SH, Rajeev V, Fann DY, Jo DG, Arumugam TV. Intermittent fasting increases adult hippocampal neurogenesis. Brain Behav. 2020 Jan;10(1):e01444.

68. Lei X, Wu Y, Xu M, Jones OD, Ma J, Xu X. Physical exercise: bulking up neurogenesis in human adults. Cell Biosci. 2019 Sep 3:9:74.

69. Yau SY, Gil-Mohapel J, Christie BR, So KF. Physical exercise-induced adult neurogenesis: a good strategy to prevent cognitive decline in neurodegenerative diseases? Biomed Res Int. 2014;2014:403120.

70. Poulose SM, Miller MG, Scott T, ShukittHale B. Nutritional Factors Affecting Adult Neurogenesis and Cognitive Function. $A d v$ Nutr. 2017 Nov 15;8(6):804-811.

71. Øverli $\varnothing$, Sørensen $C$. On the Role of Neurogenesis and Neural Plasticity in the Evolution of Animal Personalities and Stress Coping Styles. Brain Behav Evol. 2016;87(3):167-74.

72. Lyons DM, Buckmaster PS, Lee AG, Wu C, Mitra R, Duffey LM, Buckmaster CL, Her S, Patel PD, Schatzberg AF. Stress coping stimulates hippocampal neurogenesis in adult monkeys. Proc Natl Acad Sci U S A. 2010 Aug 17;107(33):14823-7.

73. Papale LA, Seltzer LJ, Madrid A, Pollak SD, Alisch RS. Differentially Methylated Genes in Saliva are linked to Childhood Stress. Sci Rep. 2018 Jul 17;8(1):10785.

74. Jiang S, Postovit L, Cattaneo A, Binder EB, Aitchison KJ. Epigenetic Modifications in Stress Response Genes Associated With Childhood Trauma. Front Psychiatry. 2019 Nov 8;10:808.

75. Gudsnuk K, Champagne FA. Epigenetic influence of stress and the social environment. ILAR J. 2012;53(3-4):279-88.

76. Ein-Dor T, Verbeke WJMI, Mokry M, Vrtička P. Epigenetic modification of the oxytocin and glucocorticoid receptor genes is linked to attachment avoidance in young adults. Attach Hum Dev. 2018 Aug;20(4):439-454.

77. Roberts S, Lester KJ, Hudson JL, Rapee RM, Creswell C, Cooper PJ, Thirlwall KJ, Coleman JR, Breen G, Wong CC, Eley TC. Serotonin transporter corrected. methylation and response to cognitive behaviour therapy in children with anxiety disorders. Transl Psychiatry. 2014 Sep 16;4(9):e444. Erratum in: Transl Psychiatry. 2014;4:e467.

78. Miller CWT. Epigenetic and Neural Circuitry Landscape of Psychotherapeutic Interventions. Psychiatry J. 2017; 2017:5491812.

79. Tiffon C. The Impact of Nutrition and Environmental Epigenetics on Human Health and Disease. Int J Mol Sci. 2018 Nov 1;19(11):3425

80. Barrón-Cabrera E, Ramos-Lopez O, González-Becerra K, Riezu-Boj JI, Milagro FI, Martínez-López E, Martínez JA. Epigenetic Modifications as Outcomes of Exercise Interventions Related to Specific 
Metabolic Alterations: A Systematic Review. Lifestyle Genom. 2019;12(1-6):25-44.

81. Alegría-Torres JA, Baccarelli A, Bollati V. Epigenetics and lifestyle. Epigenomics. 2011 Jun;3(3):267-77.

82. Cole SW. The Conserved Transcriptional Response to Adversity. Curr Opin Behav Sci. 2019 Aug;28:31-37.

83. Boyle CC, Cole SW, Dutcher JM, Eisenberger NI, Bower JE. Changes in eudaimonic well-being and the conserved transcriptional response to adversity in younger breast cancer survivors. Psychoneuroendocrinology. 2019 May;103:173-79.

84. Epel ES. Telomeres in a life-span perspective: a new "psychobiomarker"? Curr Dir Psychol Sci. 2009;18:6-10.

85. Sibille KT, Witek-Janusek L, Mathews HL, Fillingim RB. Telomeres and epigenetics: potential relevance to chronic pain. Pain. 2012 Sep;153(9):1789-93.

86. Asok A, Bernard K, Rosen JB, Dozier M, Roth TL. Infant-caregiver experiences alter telomere length in the brain. PLoS One. 2014 Jul 1;9(7):e101437.

87. Bartley EJ, Palit S, Fillingim RB, Robinson ME. Multisystem Resiliency as a Predictor of Physical and Psychological Functioning in Older Adults With Chronic Low Back Pain. Front Psychol. 2019 Aug 22;10:1932.

88. Puterman E, Epel ES, Lin J, Blackburn EH, Gross JJ, Whooley MA, Cohen BE. Multisystem resiliency moderates the major depression-telomere length association: findings from the Heart and Soul Study. Brain Behav Immun. 2013 Oct;33:65-73.

89. Boccardi V, Paolisso G, Mecocci P. Nutrition and lifestyle in healthy aging: the telomerase challenge. Aging (Albany NY). 2016 Jan;8(1):12-5.

90. Ling C, Rönn T. Epigenetics in Human Obesity and Type 2 Diabetes. Cell Metab. 2019 May 7;29(5):1028-1044.

91. Fitzgerald KN, Hodges, R, Hanes D, Stack E, Cheishvili, D, Szyf M, Henkel J, Twedt MW, Giannopoulou, D, Herdell, J, Logan, S, Bradley, R. Potential reversal of epigenetic age using a diet and lifestyle intervention: a pilot randomized clinical trial. Aging. 2021;13(7):9419-32.

92. Alegría-Torres JA, Baccarelli A, Bollati V. Epigenetics and lifestyle. Epigenomics. 2011 Jun;3(3):267-77.

93. Bókkon I, Vas JP, Császár N, Lukács T. Challenges to free will: transgenerational epigenetic information, unconscious processes, and vanishing twin syndrome. Rev Neurosci. 2014;25(1):163-75.

94. Waggoner MR, Uller T. Epigenetic Determinism in Science and Society. New Genet Soc. 2015 Apr 3;34(2):177-195.

95. McBride CM, Koehly LM. Imagining roles for epigenetics in health promotion research. J Behav Med. 2017 Apr;40(2):229-38.

96. Meissner K, Kohls N, Colloca L. Introduction to placebo effects in medicine: mechanisms and clinical implications.
Philos Trans R Soc Lond B Biol Sci. 2011 Jun 7;366(1572):1783-9.

97. Finniss DG. Placebo Effects: Historical and Modern Evaluation. Int Rev Neurobiol. 2018:139:1-27.

98. Turner JA, Deyo RA, Loeser JD, Von Korff $M$, Fordyce WE. The importance of placebo effects in pain treatment and research. JAMA. 1994 May 25;271(20):1609-14.

99. Diener HC. Placebo effects in treating migraine and other headaches. Curr Opin Investig Drugs. 2010 Jul;11(7):735-9.

100.Darragh M, Yow B, Kieser A, Booth RJ, Kydd RR, Consedine NS. A take-home placebo treatment can reduce stress, anxiety and symptoms of depression in a non-patient population. Aust N Z J Psychiatry. 2016 Sep;50(9):858-65.

101.Abdullah N. THU0189 Placebo Effect in the Treatment of Rheumatoid Arthritis: A Systematic Review and Meta-Analysis of Randomized Controlled Trials. Ann Rheum Dis. 2015;74:263.

102.Faig-Martí J, Martínez-Catassús A. Measuring the placebo effect in carpal tunnel syndrome. J Orthop Traumatol. 2020 Jan 28;21(1):1.

103.Chen X, Zou K, Abdullah N, Whiteside N, Sarmanova A, Doherty M, Zhang W. The placebo effect and its determinants in fibromyalgia: meta-analysis of randomised controlled trials. Clin Rheumatol. 2017 Jul;36(7):1623-30.

104.Narkus A, Lehnigk U, Haefner D, Klinger R, Pfaar O, Worm M. The placebo effect in allergen-specific immunotherapy trials. Clin Transl Allergy. 2013 Dec 21;3(1):42.

105. Kaptchuk TJ, Hemond CC, Miller FG. Placebos in chronic pain: evidence, theory, ethics, and use in clinical practice. BMJ. 2020 Jul 20;370:m1668.

106.de Craen AJ, Moerman DE, Heisterkamp SH, Tytgat GN, Tijssen JG, Kleijnen J. Placebo effect in the treatment of duodenal ulcer. Br J Clin Pharmacol. 1999 Dec;48(6):853-60

107.Peciña M, Bohnert AS, Sikora M, Avery ET, Langenecker SA, Mickey BJ, Zubieta JK. Association Between Placebo-Activated Neural Systems and Antidepressant Responses: Neurochemistry of Placebo Effects in Major Depression. JAMA Psychiatry. 2015 Nov;72(11):1087-94.

108. Chvetzoff G, Tannock IF. Placebo effects in oncology. J Natl Cancer Inst. 2003 Jan 1;95(1):19-29.

109.Junior PNA, Barreto CMN, de Iracema Gomes Cubero D, Del Giglio A. The efficacy of placebo for the treatment of cancerrelated fatigue: a systematic review and meta-analysis. Support Care Cancer. 2020 Apr;28(4):1755-64.

110. Hall KT, Loscalzo J, Kaptchuk TJ. Genetics and the placebo effect: the placebome. Trends Mol Med. 2015 May;21(5):285-94.

111. Benedetti F, Mayberg HS, Wager TD, Stohler CS, Zubieta JK. Neurobiological mechanisms of the placebo effect. $J$ Neurosci. 2005 Nov 9;25(45):10390-402.
112. Chang WY. Complete spontaneous regression of cancer: four case reports, review of literature, and discussion of possible mechanisms involved. Hawaii Med J. 2000 Oct;59(10):379-87.

113. Kalialis LV, Drzewiecki KT, Mohammadi M, Mehlsen AB, Klyver H. Spontaneous regression of metastases from malignant melanoma: a case report. Melanoma Res. 2008;18(4):279-83.

114. Horino T, Takao T, Yamamoto M, Geshi T, Hashimoto K. Spontaneous remission of small cell lung cancer: a case report and review in the literature. Lung Cancer. 2006 Aug;53(2):249-52.

115. Heianna J, Miyauchi T, Suzuki T, Ishida H, Hashimoto M, Watarai J. Spontaneous regression of multiple lung metastases following regression of hepatocellular carcinoma after transcatheter arterial embolization. A case report. Hepatogastroenterology. 2007 Jul-Aug; 54(77):1560-2.

116. Abdelrazeq AS. Spontaneous regression of colorectal cancer: a review of cases from 1900 to 2005. Int J Colorectal Dis. 2007 Jul;22(7):727-36.

117.Papac RJ. Spontaneous regression of cancer. Cancer Treat Rev. 1996 Nov;22(6):395-423.

118. Chohan MBY, Taylor N, Coffin C, Burak KW, Bathe OF. Spontaneous Regression of Hepatocellular Carcinoma and Review of Reports in the Published English Literature. Case Rep Med. 2019 Mar 31; 2019:9756758.

119. Kuwal A, Chauhan N, Dutt N, Elhence P, Advani M, Kumar S. Spontaneous Partial Regression of a Carcinoid Tumor: Radiology May Not Capture the Real Picture. Turk Thorac J. 2019 Jan 31; 20(2):153-6.

120. Harris WS, Gowda M, Kolb JW, Strychacz CP, Vacek JL, Jones PG, Forker A, O'Keefe $\mathrm{JH}, \mathrm{McC}$ allister BD. A randomized, controlled trial of the effects of remote, intercessory prayer on outcomes in patients admitted to the coronary care unit. Arch Intern Med. 1999 Oct 25;159(19):2273-8.

121.Schilder JN, de Vries MJ, Goodkin K, Antoni M. Psychological Changes Preceding Spontaneous Remission of Cancer. Clin Case Stud 2004;3(4):288-312.

122. Eccles R. The power of the placebo. Curr Allergy Asthma Rep. 2007 May; 7(2):100-4.

123. Chiffi D, Zanotti R. Knowledge and Belief in Placebo Effect. J Med Philos. 2017 Feb;42(1):70-85.

124. Schienle A, Gremsl A, Wabnegger A. Placebo Effects in the Context of Religious Beliefs and Practices: A Resting-State Functional Connectivity Study. Front Behav Neurosci. 2021 May 6:15:653359.

125.Schwartz JM, Stoessel PW, Baxter LR Jr, Martin KM, Phelps ME. Systematic changes in cerebral glucose metabolic rate after successful behavior modification treatment of obsessive-compulsive disorder. Arch Gen Psychiatry. 1996 Feb;53(2):109-13. 
126. Nechvatal JM, Lyons DM. Coping changes the brain. Front Behav Neurosci. 2013 Feb 22;7:13.

127.Schwartz JM. A role for volition and attention in the generation of new brain circuitry. Toward a neurobiology of mental force. J Conscious Stud. 1999; 6(8-9):115-42.

128. Nechvatal JM, Lyons DM. Coping changes the brain. Front Behav Neurosci. 2013 Feb 22;7:13.

129. Crum AJ, Langer EJ. Mind-set matters: exercise and the placebo effect. Psychol Sci. 2007 Feb;18(2):165-71

130.Lamme VA. Separate neural definitions of visual consciousness and visual attention; a case for phenomenal awareness. Neural Netw. 2004 Jun-Jul;17(5-6):861-72.

131.Lamme VA. Why visual attention and awareness are different. Trends Cogn Sci. 2003 Jan; 7(1):12-18.

132. Jueptner M, Stephan KM, Frith CD, Brooks DJ, Frackowiak RS, Passingham RE. Anatomy of motor learning. I. Frontal cortex and attention to action. J Neurophysiol. 1997 Mar;77(3):1313-24.

133.Draganski B, Gaser C, Kempermann G, Kuhn HG, Winkler J, Büchel C, May A. Temporal and spatial dynamics of brain structure changes during extensive learning. J Neurosci. 2006 Jun 7;26(23):6314-7.

134.Aydin K, Ucar A, Oguz KK, Okur OO, Agayev A, Unal Z, Yilmaz S, Ozturk C. Increased gray matter density in the parietal cortex of mathematicians: a voxel-based morphometry study. AJNR Am J Neuroradiol. 2007 Nov-Dec;28(10):1859-64

135.Lazar SW, Kerr CE, Wasserman RH, Gray $J R$, et al. Meditation experience is associated with increased cortical thickness. Neuroreport. 2005 Nov 28:16(17):1893-7.

136.Cf. Briggs F, Mangun GR, Usrey WM. Attention enhances synaptic efficacy and the signal-to-noise ratio in neural circuits. Nature. 2013 Jul 25;499(7459):476-80.

137. Buccino G, Binkofski F, Fink GR, Fadiga L, et al. Action observation activates premotor and parietal areas in a somatotopic manner: an fMRI study. Eur J Neurosci. 2001 Jan;13(2):400-4

138. Porro CA, Facchin P, Fusi S, Dri G, Fadiga $L$. Enhancement of force after action observation: behavioural and neurophysiological studies. Neuropsychologia. 2007 Oct 1; 45(13):3114-21.

139. Ertelt D, Small S, Solodkin A, Dettmers C, McNamara A, Binkofski F, Buccino G. Action observation has a positive impact on rehabilitation of motor deficits after stroke. Neuroimage. 2007;36 Suppl 2:T164-73.

140.Pascual-Leone A, Nguyet D, Cohen LG, Brasil-Neto JP, Cammarota A, Hallett M. Modulation of muscle responses evoked by transcranial magnetic stimulation during the acquisition of new fine motor skills. J Neurophysiol. 1995 Sep;74(3):1037-45.
141.Pascual-Leone A, Amedi A, Fregni F, Merabet LB. The plastic human brain cortex. Annu Rev Neurosci. 2005; 28:377-401.

142. Ehrsson HH, Geyer S, Naito E. Imagery of voluntary movement of fingers, toes, and tongue activates corresponding body-partspecific motor representations. $J$ Neurophysiol. 2003 Nov;90(5):3304-16.

143. Ranganathan VK, Siemionow V, Liu JZ, Sahgal V, Yue GH. From mental power to muscle power-gaining strength by using the mind. Neuropsychologia. 2004; 42(7):944-56

144. Yue G, Cole KJ. Strength increases from the motor program: comparison of training with maximal voluntary and imagined muscle contractions. J Neurophysiol. 1992 May;67(5):1114-23.

145. Holden-Lund C. Effects of relaxation with guided imagery on surgical stress and wound healing. Res Nurs Health. 1988 Aug;11(4):235-44.

146. Fors EA, Sexton H, Götestam KG. The effect of guided imagery and amitriptyline on daily fibromyalgia pain: a prospective, randomized, controlled trial. J Psychiatr Res. 2002 May-Jun;36(3):179-87.

147.Page SJ, Levine P, Leonard AC. Effects of mental practice on affected limb use and function in chronic stroke. Arch Phys Med Rehabil. 2005 Mar;86(3):399-402.

148.Carrico DJ, Peters KM, Diokno AC. Guided imagery for women with interstitial cystitis: results of a prospective, randomized controlled pilot study. J Altern Complement Med. 2008 Jan-Feb;14(1):53-60.

149.Cramer SC, Orr EL, Cohen MJ, Lacourse MG. Effects of motor imagery training after chronic, complete spinal cord injury. Exp Brain Res. 2007 Feb;177(2):233-42.

150.Freeman LW, Welton D. Effects of imagery, critical thinking, and asthma education on symptoms and mood state in adult asthma patients: a pilot study. J Altern Complement Med. 2005 Feb;11(1):57-68.

151. Tamir R, Dickstein R, Huberman M. Integration of motor imagery and physical practice in group treatment applied to subjects with Parkinson's disease. Neurorehabil Neural Repair. 2007 Jan-Feb;21(1):68-75.

152.Freeman L, Cohen L, Stewart M, White R, Link J, Palmer JL, Welton D. Imagery intervention for recovering breast cancer patients: clinical trial of safety and efficacy. J Soc Integr Oncol. 2008 Spring;6(2):67-75.

153.Baird CL, Sands LP. Effect of guided imagery with relaxation on health-related quality of life in older women with osteoarthritis. Res Nurs Health. 2006 Oct;29(5):442-51.

154.Louie SW. The effects of guided imagery relaxation in people with COPD. Occup Ther Int. 2004;11(3):145-59.

155.Luberto CM, Hall DL, Park ER, Haramati A Cotton S. A Perspective on the Similarities and Differences Between Mindfulness and Relaxation. Glob Adv Health Med. 2020 Feb 5.9.2164956120905597.
156. Goldin PR, Gross JJ. Effects of mindfulness-based stress reduction (MBSR) on emotion regulation in social anxiety disorder. Emotion. 2010 Feb;10(1):83-91.

157. Brower V. Mind-body research moves towards the mainstream. EMBO Rep. 2006 Apr:7(4):358-61.

158.Cushing RE, Braun KL. Mind-Body Therapy for Military Veterans with Post-Traumatic Stress Disorder: A Systematic Review. J Altern Complement Med. 2018 Feb;24(2):106-114.

159.Khusid MA, Vythilingam M. The Emerging Role of Mindfulness Meditation as Effective Self-Management Strategy, Part 1: Clinical Implications for Depression, Post-Traumatic Stress Disorder, and Anxiety. Mil Med. 2016 Sep;181(9):961-8.

160.Scott J, Teasdale JD, Paykel ES, Johnson AL, Abbott R, Hayhurst H, Moore R, Garland A. Effects of cognitive therapy on psychological symptoms and social functioning in residual depression. $\mathrm{Br} \mathrm{J}$ Psychiatry. 2000 Nov;177:440-6.

161.Jacobs TL, Shaver PR, Epel ES, Zanesco AP, et al. Self-reported mindfulness and cortisol during a Shamatha meditation retreat. Health Psychol. 2013 Oct;32(10):1104-9.

162.Rosenzweig S, Reibel DK, Greeson JM, Edman JS, Jasser SA, McMearty KD, Goldstein BJ. Mindfulness-based stress reduction is associated with improved glycemic control in type 2 diabetes mellitus: a pilot study. Altern Ther Health Med. 2007 Sep-Oct;13(5):36-8.

163. Hölzel BK, Carmody J, Vangel M, Congleton C, Yerramsetti SM, Gard T, Lazar SW. Mindfulness practice leads to increases in regional brain gray matter density. Psychiatry Res. 2011 Jan 30;191(1):36-43.

164.Gross CR, Kreitzer MJ, Russas V, Treesak C, Frazier PA, Hertz MI. Mindfulness meditation to reduce symptoms after organ transplant: a pilot study. Adv Mind Body Med. 2004 Summer;20(2):20-9.

165.Carlson LE, Speca M, Patel KD, Goodey E. Mindfulness-based stress reduction in relation to quality of life, mood, symptoms of stress, and immune parameters in breast and prostate cancer outpatients. Psychosom Med. 2003 Jul-Aug; 65(4):57181.

166. Carlson LE, Speca M, Faris P, Patel KD. One year pre-post intervention follow-up of psychological, immune, endocrine and blood pressure outcomes of mindfulnessbased stress reduction (MBSR) in breast and prostate cancer outpatients. Brain Behav Immun. 2007 Nov;21(8):1038-49.

167.Speca M, Carlson LE, Goodey E, Angen M. A randomized, wait-list controlled clinical trial: the effect of a mindfulness meditationbased stress reduction program on mood and symptoms of stress in cancer outpatients. Psychosom Med. 2000 Sep-Oct;62(5):613-22. 
168. Rosenkranz MA, Davidson RJ, Maccoon DG, Sheridan JF, Kalin NH, Lutz A. A comparison of mindfulness-based stress reduction and an active control in modulation of neurogenic inflammation. Brain Behav Immun. 2013 Jan; 27(1):174-84.

169.Cf. McClelland DC, Kirshnit. C. The effect of motivational arousal through films on salivary immunoglobulin A. Psychology and Health. 1998;2:31-52.

170.Davidson RJ. The Emotional Life of Your Brain: How Its Unique Patterns Affect the Way You Think, Feel, and Live - and How You Can Change Them, Avery; 2012.

171.Desbordes G, Negi LT, Pace TW, Wallace BA, Raison CL, Schwartz EL. Effects of mindful-attention and compassion meditation training on amygdala response to emotional stimuli in an ordinary, non-meditative state. Front Hum Neurosci. 2012 Nov 1;6:292.

172.Klimecki OM, Leiberg S, Lamm C, Singer T. Functional neural plasticity and associated changes in positive affect after compassion training. Cereb Cortex. 2013 Jul;23(7):1552-61.
173.Newberg A. The brain and the biology of belief: An interview with Andrew Newberg, MD. Interview by Nancy Nachman-Hunt. Adv Mind Body Med. 2009 Spring;24(1):32-6.

174.Werk RS, Steinhorn DM, Newberg A. The Relationship Between Spirituality and the Developing Brain: A Framework for Pediatric Oncology. J Relig Health. 2021 Feb;60(1):389-405.

175.Koenig HG. Religion, Spirituality, and Health: The Research and Clinical Implications. International Scholarly Research Network ISRN Psychiatry. 2012.

176. Bonelli RM, Koenig HG. Mental disorders, religion and spirituality 1990 to 2010 : a systematic evidence-based review. J Relig Health. 2013 Jun;52(2):657-73.

177. Koenig HG, Al Zaben FN, Al Shohaib S. Religion and Health: Clinical Considerations and Applications, International Encyclopedia of the Social \& Behavioral Sciences, 2nd edition, Volume 20:262-8.

178. Rossi EL. Psychobiology of Gene Expression, Neuroscience and Neurogenesis in Hypnosis and the Healing Arts, WW Norton, 2002.
179.Dusek JA, Otu HH, Wohlhueter AL, Bhasin M, Zerbini LF, Joseph MG, Benson H, Libermann TA. Correction: Genomic Counter-Stress Changes Induced by the Relaxation Response. PLoS One. 2017 Feb 21;12(2):e0172845.

180.Jacobs TL, Epel ES, Lin J, Blackburn EH, et al. Intensive meditation training, immune cell telomerase activity, and psychological mediators. Psychoneuroendocrinology. 2011 Jun;36(5):664-81.

181. Schutte NS, Malouff JM. A meta-analytic review of the effects of mindfulness meditation on telomerase activity. Psychoneuroendocrinology. 2014 Apr;42:45-8.

182.Conroy D, Hagger MS. Imagery interventions in health behavior: A meta-analysis. Health Psychol. 2018 Jul;37(7):668-679.

183.Jiménez JP, Botto A, Herrera L, Leighton C, Rossi JL, et al. Psychotherapy and Genetic Neuroscience: An Emerging Dialog. Front Genet. 2018 Jul 17;9:257. 